\title{
The Concept of Geologic Carbon Sequestration
}

Geologic carbon sequestration is a method of securing carbon dioxide $\left(\mathrm{CO}_{2}\right)$ in deep geologic formations to prevent its release to the atmosphere and contribution to global warming as a greenhouse gas. The figure illustrates some of the major concepts associated with geologic carbon sequestration. The figure is not to scale.

Earth's carbon cycle is the movement of carbon through the planet's atmospheric, biologic, geologic, and hydrologic systems (Sundquist and others, 2008). As illustrated in the figure, many activities of modern human life have altered the carbon cycle by increasing the amount of $\mathrm{CO}_{2}$ produced. For example, power generating facilities, petrochemical plants, cement production plants, cars and trucks, industrial processes, and agricultural practices all produce $\mathrm{CO}_{2}$ and release it into the environment. Some of this $\mathrm{CO}_{2}$ is sequestered naturally in oceans, plants, and soils, but an increasing amount is making its way into the atmosphere. Additional forms of carbon sequestration are desirable to offset these increasing emissions.

Carbon dioxide can be captured from stationary sources, such as powerplants and other large industrial facilities, compressed to a fluid state, and injected deep underground into permeable and porous geologic strata in which it will remain isolated for long periods of time. This process reduces or eliminates the emission of $\mathrm{CO}_{2}$ into the atmosphere. The geologic formation in which the gas is stored must be overlain by another layer of impermeable rock to seal in the injected $\mathrm{CO}_{2}$. In the figure, injection wells are depicted as columns of brown "bubbles" with arrows pointed downward into the earth. Brown bubbles in the storage formation represent geologic storage of $\mathrm{CO}_{2}$.

The technology for sequestering $\mathrm{CO}_{2}$ is still being developed, although a few industrial-sized carbon sequestration projects are operating worldwide. Several are associated with offshore natural gas production, as depicted by the offshore platform at the far right of the figure. In addition, for many decades $\mathrm{CO}_{2}$ has been injected into geologic formations to boost production from oilfields by displacing trapped oil and gas. This process, known as enhanced oil recovery, has not been optimized for storage of $\mathrm{CO}_{2}$, although significant experience has been gained in handling carbon dioxide, including how to ship it through pipelines, how to prevent leakage by plugging abandoned wells, and how to construct injection wells and inject $\mathrm{CO}_{2}$ into them.

Determining the amount of $\mathrm{CO}_{2}$ that can be sequestered nationally is important so that long-term plans can be made to capture and store $\mathrm{CO}_{2}$. Toward this end, the U.S. Geological Survey (USGS) has developed a method for assessing the amount of $\mathrm{CO}_{2}$ that might be sequestered in geologic formations (Brennan and others, 2010). As illustrated in the figure, the method developed by the USGS considers two main types of trapping to determine the technically accessible storage resource - that is, the amount of $\mathrm{CO}_{2}$ that can be stored using current technology. One type, known as buoyant trapping, fills the pore space in the rock with $\mathrm{CO}_{2}$; the $\mathrm{CO}_{2}$ is held in place by seal formations on the top and sides of the porous rock. This type of trapping is somewhat analogous to how oil and gas are trapped and is illustrated in the figure by the accumulation of $\mathrm{CO}_{2}$ in arc-shaped structures (anticlines) that are overlain by low-permeability seal formations that prevent upward leakage. The other type of trapping, known as residual trapping, occurs as injected $\mathrm{CO}_{2}$ passes through the storage formation and leaves some $\mathrm{CO}_{2}$ behind; the $\mathrm{CO}_{2}$ is held in place by surface tension in pore spaces. This type of trapping retains less $\mathrm{CO}_{2}$ per given rock volume, but there is much more rock for which this type of trapping applies.

\section{References Cited}

Brennan, S.T., Burruss, R.C., Merrill, M.D., Freeman, P.A., and Ruppert, L.F., 2010, A probabilistic assessment methodology for the evaluation of geologic carbon dioxide storage: U.S. Geological Survey Open-File Report 2010-1127, 31 p., available only at http://pubs.usgs.gov/ of/2010/1127/.

Sundquist, Eric, Burruss, Robert, Faulkner, Stephen, Gleason, Robert, Harden, Jennifer, Kharaka, Yousif, Tieszen, Larry, and Waldrop, Mark, 2008, Carbon sequestration to mitigate climate change: U.S. Geological Survey Fact Sheet 20083097, 4 p., available at $h t t p: / / p u b s . u s g s . g o v / f s / 2008 / 3097 /$.

\section{By Douglas W. Duncan and Eric A. Morrissey}

\section{For More Information}

\section{U.S. Geological Survey}

Energy Resources Program

12201 Sunrise Valley Drive, MS 915A

Reston, VA 20192

Internet: http://energy.usgs.gov/ 


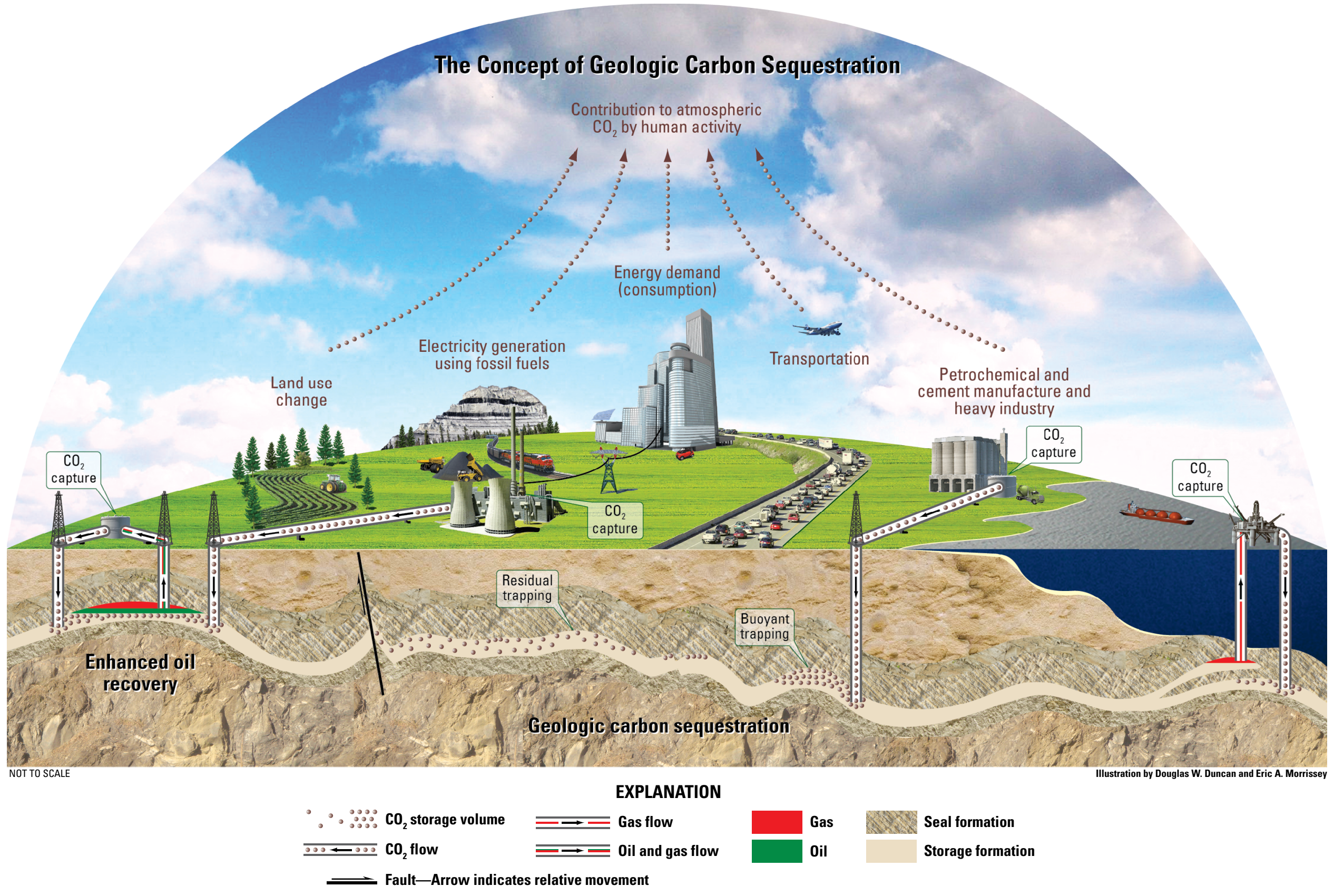

Figure 1. Figure illustrating the concept of geologic carbon sequestration. Figure composed by Douglas W. Duncan and illustrated by Eric A. Morrissey. 